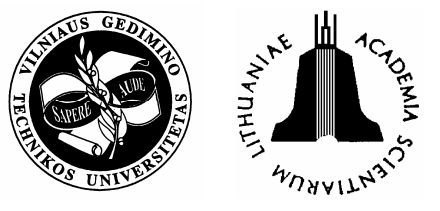

\title{
THE HEATING RATE IMPACT ON PARAMETERS CHARACTERISTIC OF STEEL BEHAVIOUR UNDER FIRE CONDITIONS
}

\author{
Zoja Bednarek, Renata Kamocka \\ The Main School of Fire Service (MSFS) in Warsaw, J. Stowackiego Str. 52/54, \\ 01-629 Warsaw, Poland. E-mail: sgsp@sgsp.edu.pl \\ Received 5 Oct 2005; accepted 29 May 2006
}

\begin{abstract}
The behaviour of steel structure components within a high temperature field depends not only on the absolute temperature, but also on the temperature vs time function and on the heating rate, $\mathrm{dT} / \mathrm{d} \tau$. The research objective is the determination of the heating rate impact on selected strength parameters of structural steels. Tests were performed under conditions of a linear temperature increase with different heating rates and with a constant stress value, $\sigma / f_{y}$. After strength tests, the samples were subjected to metallography. Test results proved that the heating rate makes a significant impact on parameters that determine the steel structure bearing capacity at higher temperatures and that the heating rate should be accounted for in the strength analysis of steel structures exposed to high temperatures.
\end{abstract}

Keywords: structural steel, heating rate, fire conditions, critical deformation, critical temperature, strength tests.

\section{Introduction}

Tests of structural materials, including steel, as performed in order to find parameters necessary for the limit state analysis of steel structures under thermal conditions as occur in fire, are divided into two groups:

- tests of materials thermal properties varying at high temperatures in order to find the temperature vs time relation/function for structural components,

- strength tests under determined thermal conditions in order to select parameters required for the in-fire bearing capacity limit state analysis.

The analysis of steel structure strength and deformation in a high temperature requires some regard to material creeping as a time-related effect. Under the conditions of unstable creeping at constant stress level $\sigma / f_{y}$ and at on increasing temperature, it is not only the absolute temperature that must be regarded but also the temperature vs time relation, and the heating rate $d T / d \tau$ in particular, as indicated by the following papers: [1-5], and by the authors' research results discussed in this paper.

Papers by Stowell [5], Anderberg [1], Skowroński [3, 4], Mäkeläinen [2], and those on metal structure phenomena under a high-rate temperature rise conditions indicate a significant impact of the heating rate on deformation and strength of structural materials.

Fig 1 shows high-heating-rate profiles for 7075-T6 aluminium sheet of three stress figures within a wide temperature range. The plot was made by Stowell.

Anderberg used the analytical model based on the modified Dorn-Harmathy theory, and assessed the tensile strength vs temperature relation for both $T=$ const and for $T \neq$ const conditions. The temperature variation rate impact for the unstable status is shown in Fig 2. The tensile

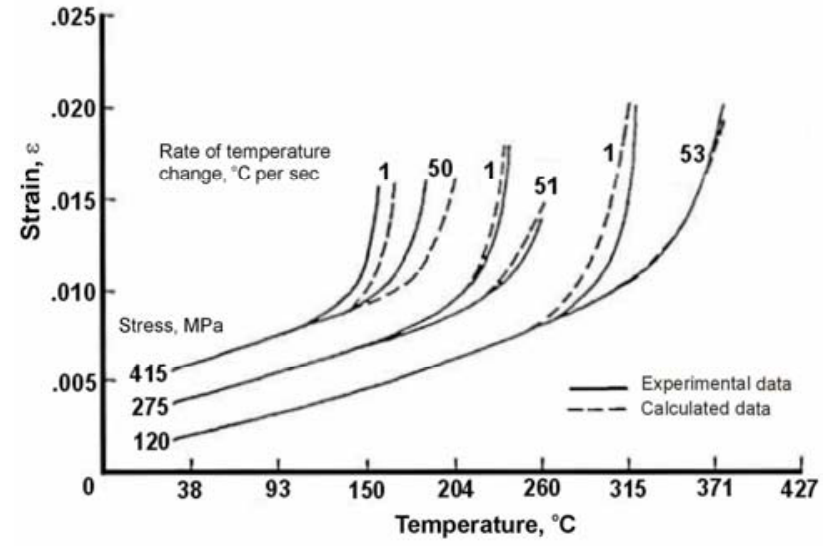

Fig 1. High-heating-rate curves for 3 stress figures, 7075-T6 aluminium alloy sheet, by Stowell [5]

strength is defined by Anderberg as the stress that results in $4 \%$ deformation (thermal deformation excluded).

Skowroński also puts emphasis on the need for regarding the heating rate and effects of the unstable creeping while analysing post-fire structural steel. Fig 3 shows ASTM A36 steel creeping deformation for two temperature increase rates: $4{ }^{\circ} \mathrm{C} / \mathrm{min}$, and $50{ }^{\circ} \mathrm{C} / \mathrm{min}$ as found by Skowroński based on the creeping model defined and described in [4] by himself. The creeping-induced deformation is bigger for the lower heating rate.

An extensive research aimed at finding structural steel tensile properties under unstable thermal conditions was also carried out by Mäkeläinen [2] at the Laboratory of Steel Structures, Helsinki University of Technology. Test results are available on the Laboratory Site: http://www.hut.fi/Units/Civil/Steel/Publications/jsarj.html. 


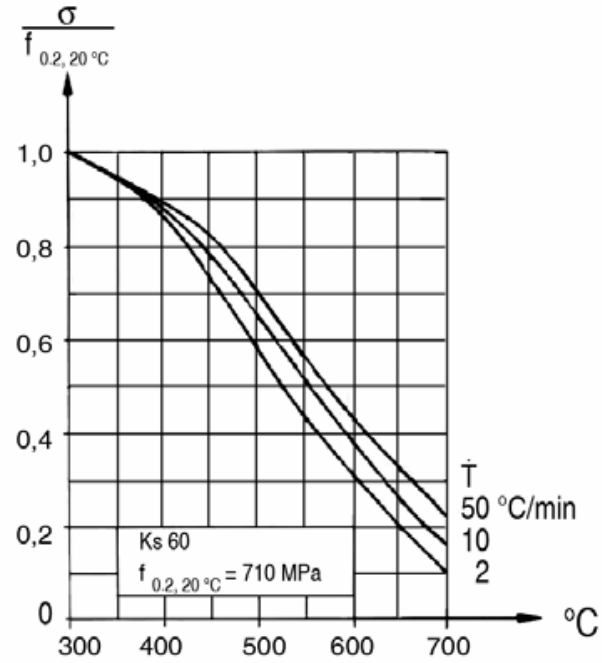

Fig 2. Tensile strength vs temperature for Ks60 steel at various heating rates [1]

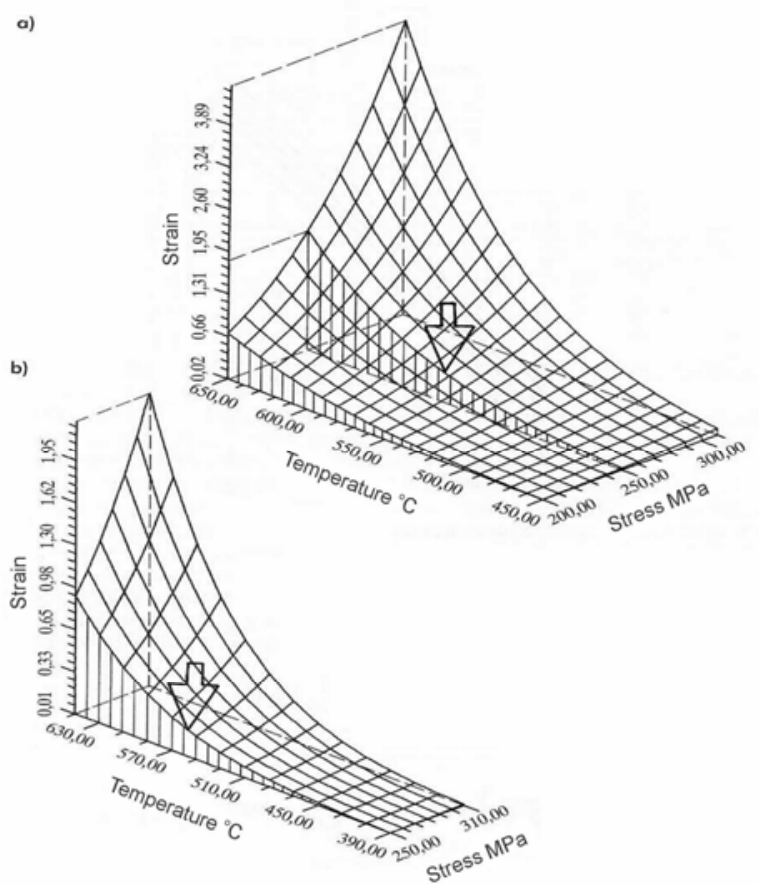

Fig 3. ASTM A36 steel creeping deformation at: a) $4{ }^{\circ} \mathrm{C} / \mathrm{min}$ temperature increase rate, b) $50{ }^{\circ} \mathrm{C} / \mathrm{min}$ temperature increase rate [4]

The analysis of current knowledge shows the need for examination and determination of the temperature vs time relation impact on steel behaviour as assumed so far for steel structural components at various heating rates under standard fire or real fire conditions.

\section{Research objective and scope}

The objective of the research at the Zakład Mechaniki Stosowanej SGSP (the SGSP Applied Mechanics Dept) was to determine strength parameters (critical temperature $T_{k r}$, and $\tau_{\mathrm{kr}}$ ) for two structural steel grades: S235JRG2 general-purpose standard steel, and S355J2G3 low-alloy high-strength steel as well as to prove that a heating rate variation makes a significant impact on those parameters. This is of importance because the Eurocode 3 [6] has adopted the principle that the critical temperature only depends on the cross-section use ratio without any regard to the heating rate.

No descriptions of similar tests were found in the literature. That's why our research results will add to a better understanding of the phenomena in steel under conditions of different heating rates.

In order to examine the behaviour of structural steels in linearly variable temperature field at different heating rates, like fire, the following tests were performed:

1. Tests of the heating rate, $d T / d \tau$, impact on the steel deformation as results of the thermal linear expansion and impact on the thermal linear expansion coefficient. The test outcomes were published in [7,8].

2. Tests of the heating rate impact on the critical temperature (damage temperature) and on the steel deformation at selected constant stress values, $\sigma / f_{y}-$ strength tests.

3. Tests of the heating rate impact and the stress level on the steel structure damage character - metallography.

Anisothermic tests were performed under conditions of linear temperature increase with different heating rates at two constant stress levels: $\sigma=0,5 f_{y}$ and $\sigma=0,8 f_{y}$. Five tests were made for each metering point.

This paper discusses the test conditions and results for groups 2 and 3.

\section{Thermal conditions}

The temperature increase analysis for fire-heated steel structures can be performed by means of nomograms as shown in Fig 4.

The figure presents a part of the Euro-Nomogram [9] and shows the temperature increase in fire for both structural components protected with an insulation coat and without any insulation.

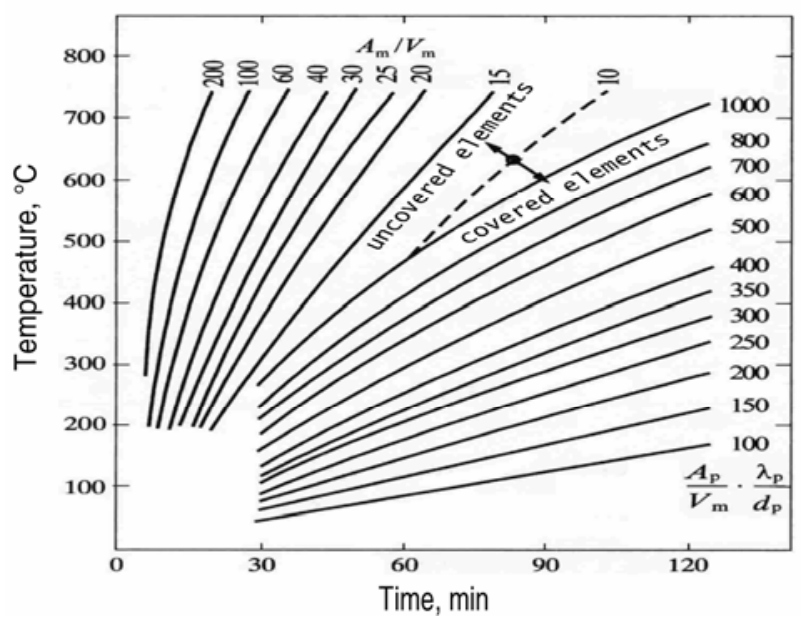

Fig 4. Nomogram showing the temperature increase within a structural component in fire [ECCS] [10] 
Simplified formulas are also known [4], that facilitate finding the relation between the temperature of an isolated element, the fire exposition time [minutes] and properties of the fire protection coat (if any).

For a non-insulated steel component:

$$
t=0,54(T-50)\left[\frac{V_{m}}{A_{m}}\right]^{0,60} .
$$

For an insulated steel component:

$$
t=40(T-140)\left[\frac{d_{p}}{\lambda_{p}} \frac{V_{m}}{A_{m}}\right]^{0,77},
$$

whereas: $t$-exposition time [min] required for reaching the temperature of $\mathrm{T}\left[{ }^{\circ} \mathrm{C}\right]$,

$$
\frac{A_{m}}{V_{m}}-\text { area/volume coefficient }\left[\mathrm{m}^{-1}\right],
$$

$\lambda_{p}$ - heat transmission coefficient for the insulation material $[\mathrm{W} / \mathrm{mK}]$,

$d_{p}$ - insulation coat thickness [m].

The temperature vs time function was adopted based on the nomogram (Fig 4) and formulas (1), (2). Linearlyincreasing temperature distribution patterns were adopted with heating rate parameters as $5{ }^{\circ} \mathrm{C} / \mathrm{min}, 20{ }^{\circ} \mathrm{C} / \mathrm{min}$, $35^{\circ} \mathrm{C} / \mathrm{min}, 50{ }^{\circ} \mathrm{C} / \mathrm{min}, 65^{\circ} \mathrm{C} / \mathrm{min}$. Fig 5 shows temperature vs time distribution applied for tests.

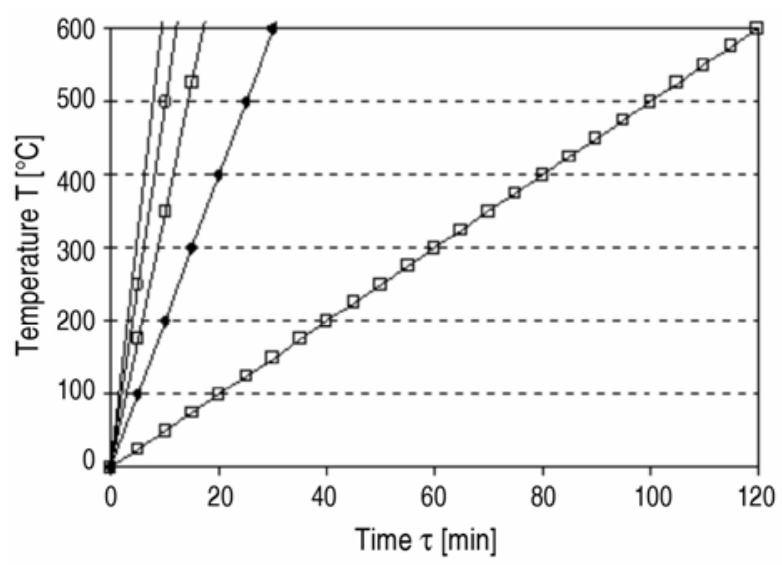

๑-5 C/min $\rightarrow-20 \mathrm{C}$ minin $\square-35 \mathrm{C}$ minin $-2-50 \mathrm{C}$ min $-65 \mathrm{C} / \mathrm{min}$

Fig 5. Temperature vs time distribution as applied for tests

\section{Planning the experiment}

The steel strength tests were performed with the experiment plan shown in Fig 6:

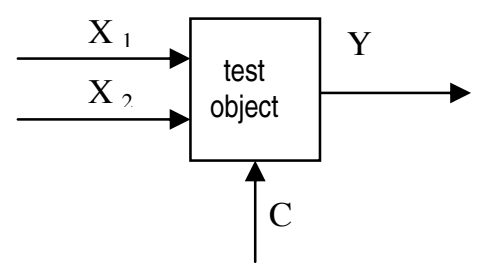

Fig 6. Experiment plan
Input variables, $X$

- $\mathrm{X}_{1}$ : heating rate $\dot{T}$,

- $X_{2}$ : stress level $\sigma / f_{y}$.

Different constant values, $C$

- steel grade.

Output variables, $Y$

- deformation vs time relation and strength profiles obtained based on the analysis of these relations: critical temperature, critical time, critical deformation.

Input variables $(X)$ scope:

- heating rates: tests were performed for five heating rates: $5{ }^{\circ} \mathrm{C} / \mathrm{min}, 20{ }^{\circ} \mathrm{C} / \mathrm{min}, 35^{\circ} \mathrm{C} / \mathrm{min}, 50{ }^{\circ} \mathrm{C} / \mathrm{min}$, $65^{\circ} \mathrm{C} / \mathrm{min}$;

- stress level, $\sigma / f_{y}$, was constant and equal to 0,5 or 0,8 .

Fig 7 shows the standardised plan of experiment.

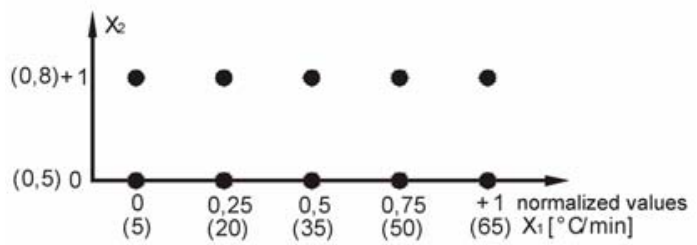

Fig 7. Standardised test points for strength tests for different heating rates

Strength profile tests for different heating rates were performed according to the multiple monoselection experiment plan (PS/DS-M:M). This plan consists in: for each test of the impact of an input value on an output value, the remaining input values are constant.

\section{Strength parameters based on tests}

All strength parameters were obtained by the analysis of "deformation-time" diagrams, and the critical parameters were obtained by the critical point as marked on this diagram. The critical point was selected in the " $\varepsilon-\tau$ " diagram as the point before the sample damage and specific for the biggest deformation acceleration $[10,11]$.

$$
\begin{aligned}
& \ddot{\varepsilon} \mathrm{i}=\frac{\mathrm{d}^{2} \varepsilon}{\mathrm{d} \tau^{2}}=\frac{\dot{\mathrm{d} \varepsilon}}{\mathrm{d} \tau}=\frac{\dot{\varepsilon i}-\dot{\varepsilon} \mathrm{i}-1}{\Delta \tau}, \\
& \dot{\varepsilon} \mathrm{i}=\frac{\Delta \varepsilon}{\Delta \tau}=\frac{\varepsilon \mathrm{i}-\varepsilon \mathrm{i}-1}{\Delta \tau} .
\end{aligned}
$$

The time length was equal to $\Delta \tau=5 \mathrm{~s}$.

Fig 8 shows how the critical point was traced.

The critical point so obtained is accompanied by parameters: $T_{k r}, \tau_{\mathrm{kr}}, \varepsilon_{\mathrm{kr} \text {. }}$

The following parameters were analysed in the research course:

$\mathrm{T}_{\mathrm{kr}}\left[{ }^{\circ} \mathrm{C}\right]$ - critical temperature;

$\mathrm{T}_{\varepsilon}\left[{ }^{\circ} \mathrm{C}\right]$ - temperature when the total deformation was achieved as required, eg $\varepsilon=1 \%$;

$\varepsilon_{\mathrm{kr}}[\%]$ - total critical deformation calculated as the sum of deformations in the critical point and of the 
deformation caused by the initial load (for reaching a determined stress level);

$\tau_{\mathrm{kr}}[\mathrm{min}]$ - time required for reaching the critical time in the $\varepsilon=f(\tau)$ diagram, ie the time from the test start (at $T_{0}=20{ }^{\circ} \mathrm{C}$ ) till reaching the critical temperature.

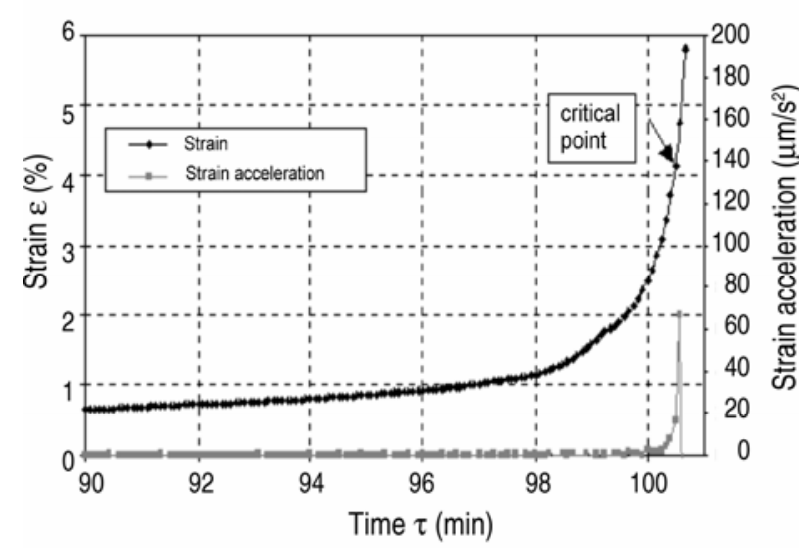

Fig 8. Tracing the critical point in the $\varepsilon=f(\tau)$ diagram

\section{Test results}

Test results were approximated with the application of the structural parameter assessment method for the regression function and with application of the smallest squares.

The following formulas were obtained for the relation of critical deformation, critical temperature and critical time to the heating rate: whereas:

$$
\varepsilon_{k r}=A(\dot{\mathrm{T}})^{\alpha}, \quad T_{k r}=B(\dot{\mathrm{T}})^{\beta} \text { and } \tau_{k r}=C(\dot{\mathrm{T}})^{\gamma},
$$

$\dot{\mathrm{T}}$ - heating rate (unitless value); $A, B, C$ - material coefficients for steel grades for stress levels as applied for tests; $\alpha, \beta, \gamma$ - material coefficients (unitless).

Tables 1 and 2 include empirical formulas that describe the parameters analysed.

Table 1. Formulas of strength parameters for S235JRG2

\begin{tabular}{|c|c|c|c|}
\hline Parameter & $\sigma / f_{y}$ & $\begin{array}{l}\text { Approximation function } \\
\text { formula }\end{array}$ & $\begin{array}{c}\text { Adaptation } \\
\text { coefficient } \\
R^{2}\end{array}$ \\
\hline $\begin{array}{l}\text { Critical tem- } \\
\text { perature } T_{k r} \\
\end{array}$ & \multirow{4}{*}{0,5} & $T_{k r}=498,23 \dot{\mathrm{T}}^{0,0341}$ & 0,9826 \\
\hline $\begin{array}{c}\text { Temperature } \\
T_{\varepsilon=1 \%} \\
\end{array}$ & & $T_{\varepsilon=1 \%}=437,31 \dot{\mathrm{T}}^{0,0531}$ & 0,972 \\
\hline $\begin{array}{l}\text { Critical de- } \\
\text { formation } \varepsilon_{\mathrm{kr}} \\
(\%)\end{array}$ & & $\varepsilon_{\mathrm{kr}}=8,3512 \dot{\mathrm{T}}^{-0,405}$ & 0,9658 \\
\hline $\begin{array}{c}\text { Critical time } \\
\tau_{\mathrm{kr}} \\
\end{array}$ & & $\tau_{\mathrm{kr}}=435,6 \dot{\mathrm{T}}^{-0,8457}$ & 0,9991 \\
\hline $\begin{array}{l}\text { Critical tem- } \\
\text { perature } T_{k r} \\
\end{array}$ & \multirow{4}{*}{0,8} & $T_{k r}=404,56 \dot{\mathrm{T}}^{0,0509}$ & 0,9769 \\
\hline $\begin{array}{c}\text { Temperature } \\
T_{\varepsilon=1 \%} \\
\end{array}$ & & $T_{\varepsilon=1 \%}=354,66 \dot{\mathrm{T}}^{0,0663}$ & 0,9241 \\
\hline $\begin{array}{l}\text { Critical de- } \\
\text { formation } \varepsilon_{\mathrm{kr}} \\
(\%)\end{array}$ & & $\varepsilon_{\mathrm{kr}}=9,7934 \dot{\mathrm{T}}^{-0,399}$ & 0,9625 \\
\hline $\begin{array}{c}\text { Critical time } \\
\tau_{\mathrm{kr}}\end{array}$ & & $\tau_{\mathrm{kr}}=373,38 \dot{\mathrm{T}}^{-0,8242}$ & 0,9999 \\
\hline
\end{tabular}

Table 2. Formulas for strength parameters of S355J2G3

\begin{tabular}{|c|c|c|c|}
\hline Parameter & $\sigma / f_{y}$ & $\begin{array}{l}\text { Approximation function } \\
\text { formula }\end{array}$ & $\begin{array}{c}\text { Adaptation } \\
\text { coefficient } \\
R^{2} \\
\end{array}$ \\
\hline $\begin{array}{l}\text { Critical tem- } \\
\text { perature } T_{k r}\end{array}$ & \multirow{4}{*}{0,5} & $T_{k r}=527,38 \dot{\mathrm{T}}^{0,0354}$ & 0,9805 \\
\hline $\begin{array}{c}\text { Temperature } \\
T_{\varepsilon=1 \%}\end{array}$ & & $T_{\varepsilon=1 \%}=451,44 \dot{\mathrm{T}}^{0,058}$ & 0,8285 \\
\hline $\begin{array}{l}\text { Critical de- } \\
\text { formation } \varepsilon_{\mathrm{kr}} \\
(\%)\end{array}$ & & $\varepsilon_{\mathrm{kr}}=6,9897 \dot{\mathrm{T}}^{-0,3822}$ & 0,9952 \\
\hline $\begin{array}{c}\text { Critical time } \\
\tau_{\mathrm{kr}} \\
\end{array}$ & & $\tau_{\mathrm{kr}}=441,18 \dot{\mathrm{T}}^{-0,8352}$ & 0,9991 \\
\hline $\begin{array}{l}\text { Critical tem- } \\
\text { perature } T_{k r}\end{array}$ & \multirow{4}{*}{0,8} & $T_{k r}=443 \dot{\mathrm{T}}^{0,0435}$ & 0,9812 \\
\hline $\begin{array}{c}\text { Temperature } \\
T_{\varepsilon=1} \%\end{array}$ & & $T_{\varepsilon=1 \%}=379,45 \dot{\mathrm{T}}^{0,06}$ & 0,9422 \\
\hline $\begin{array}{l}\text { Critical de- } \\
\text { formation } \varepsilon_{\mathrm{kr}} \\
(\%)\end{array}$ & & $\varepsilon_{\mathrm{kr}}=13,898 \dot{\mathrm{T}}^{-0,5242}$ & 0,964 \\
\hline $\begin{array}{c}\text { Critical time } \\
\tau_{\mathrm{kr}} \\
\end{array}$ & & $\tau_{\mathrm{kr}}=400,51 \dot{\mathrm{T}}^{-0,8363}$ & 0,9988 \\
\hline
\end{tabular}

Figs $9 \div 12$ present the heating rate impact on the critical temperature and on the critical deformation.

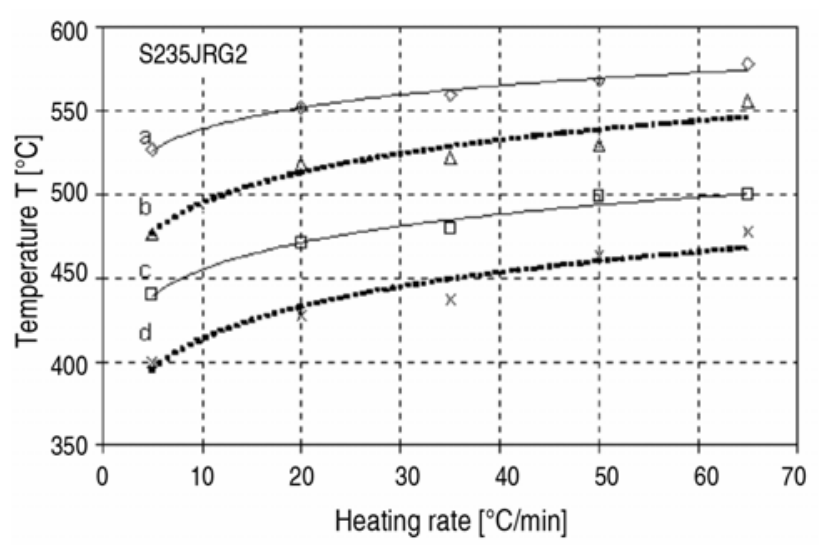

Fig 9. Heating rate impact on the critical temperature and on the deformation temperature for $\varepsilon=1 \%$ forS235JRG2 steel: (a) $T_{k r}$ at $\sigma=0,5 f_{y}$; (b) $T_{\varepsilon=1 \%}$ at $\sigma=0,5 f_{y}$; (c) $T_{k r}$ at $\sigma=0,8 f_{y}$; (d) $T_{\varepsilon=1 \%}$ at $\sigma=0,8 f_{y}$

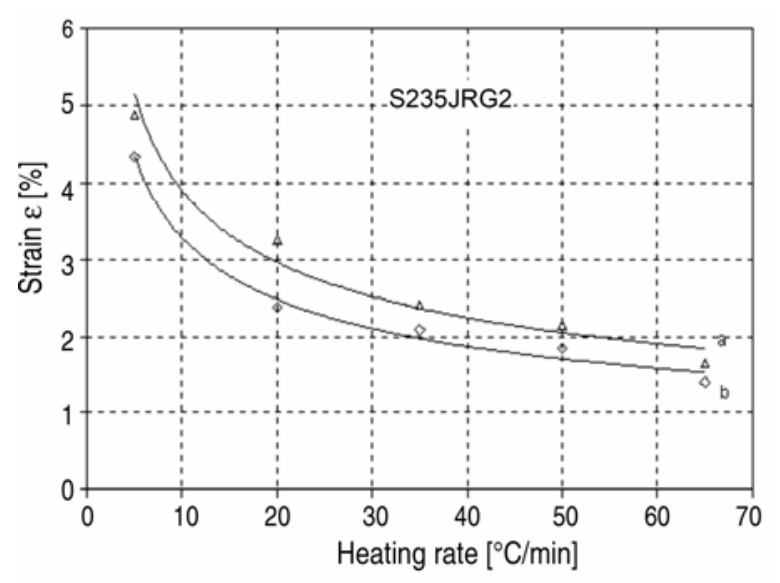

Fig 10. Heating rate impact on the critical deformation for S235JRG2 steel: (a) $\varepsilon_{k r}$ at $\sigma=0,8 f_{y}$, (b) $\varepsilon_{k r}$ at $\sigma=0,5 f_{y}$ 


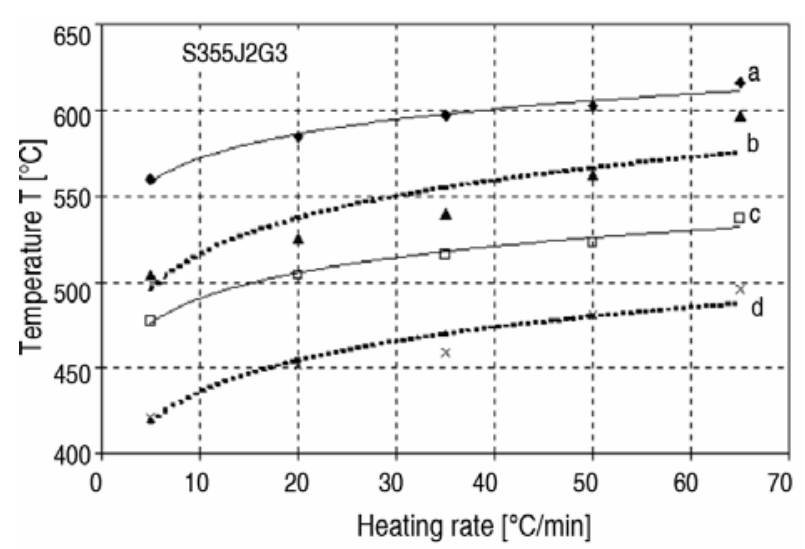

Fig 11. Heating rate impact on the critical temperature and on the deformation temperature for $\varepsilon=1 \%$ for S355J2G3 steel in two stress levels: (a) $T_{k r}$ at $\sigma=0,5 f_{y}$; (b) $T_{\varepsilon=1 \%}$ at $\sigma=0,5 f_{y}$; (c) $T_{k r}$ at $\sigma=0,8 f_{y}$; (d) $T_{\varepsilon=1 \%}$ at $\sigma=0,8 f_{y}$

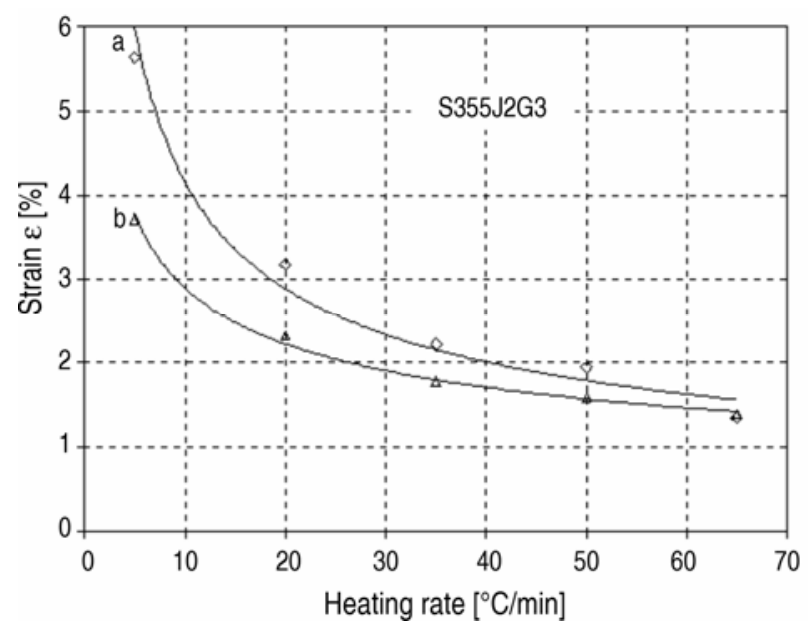

Fig 12. Heating rate impact on the critical deformation for S355J2G3 steel:(a) $\varepsilon_{k r}$ at $\sigma=0,5 f_{y}$; (b) $\varepsilon_{k r}$ at $\sigma=0,8 f_{y}$

\section{Metallography}

After tests in the linearly increasing temperature field with various heating rates, samples of S235JRG2 and S355J2G3 structural steel grades were subjected to metallography. Metallography results are a complement to the strength tests, and they also facilitate the assessment of qualitative phenomena in the structure of steel grades tested, for a correct interpretation of the phenomena observed.

The test objective was to find out whether differences in the steel microstructure can be found by qualitative optical microscopy methods for the heating rate ranges as selected $\left(5^{\circ} \mathrm{C} / \mathrm{min}\right.$ and $\left.50{ }^{\circ} \mathrm{C} / \mathrm{min}\right)$ and mechanical load as selected $\left(\sigma=0,5 f_{y}\right.$ and $\left.\sigma=0,8 f_{y}\right)$. For comparison, metallography was applied to:

1) source material for strength samples;

2) material of samples after strength tests at two different heating rates.

The structural assessment was performed with an OLYMPUS PMG3 metallography microscope. Microscope observations were made for an enlargement range between $25 \mathrm{x}$ up to $1000 \mathrm{x}$.
In order to gather a reference, a microstructure examination was performed for samples without any mechanical load. For both steel grades, pearlite and ferrite strands were found (lengthwise microsections).

The grain size is variable within a single reference, therefore, it can be assessed as the same in both steel grades.

After examining the samples microstucture of S235JRG2 steel and after etching we found: for $5{ }^{\circ} \mathrm{C} / \mathrm{min}$ and for $50{ }^{\circ} \mathrm{C} / \mathrm{min}$ heating rates at $\sigma / f_{y}=0,5$ mechanical load, that increasing the heating rate results in decreasing the deformation in the pearlite-and-ferrite areas. The same phenomenon was observed at a higher load of $\sigma / f_{y}=0,8$. A similar phenomenon was also noticed for S355J2G3 steel: a higher heating rate causes a lower deformation within pearlite-and-ferrite areas.

Fig 13 shows microstructure examples of S235JRG2 steel. The impact of a high heating rate vs. a low heating rate is visible clearly. The specific feature of microstructure modification is a significant grain elongation in the load direction for a long-time low heating rate compared to the small grain distortion or no distortion at all for the high heating rate. The stress level within the sample results in a smaller impact.

For different heating rates $\left(5^{\circ} \mathrm{C} / \mathrm{min}, 50{ }^{\circ} \mathrm{C} / \mathrm{min}\right)$, the microstructure shows significant differences among grain shapes, and reveals empty spaces of various location and size in the vicinity of fracture.

Increasing the heating rate results in decreasing the slip along grain boundaries and leads to the creation of local empty spaces of big dimensions; such spaces decrease the cross-section area and give reasons for more brittle cracking than in the case of a long-time low heating rate. Intercrystalline cracks developed at a high heating rate were created probably because grain boundaries were not able to adapt to the significant slip without creating discontinuities [12].

For a high heating rate, the time length required to achieve the damage temperature is too short. Therefore a short time length allows some plastic deformation mechanisms to perform.

The low heating rate creates a significant grain deformation within the pearlite-and-ferrite areas at both stress levels. On the contrary, such a significant grain elongation was not found for the high heating rate. The significant grain elongation in the load direction is accompanied by the damage with a higher share of the plastic fracture, whereas a small grain deformation accompanies the damage with a bigger share of a brittle fracture. The structural examination (metallography) results explain the reason of different strength test results for steel grades heated at different rates.

\section{Conclusions}

1. The phenomena occurring in structural steel grades due to high heating rates are different compared to those resulted from a constant temperature or from a long-time low heating rate. The test results discussed in this paper also indicate this phenomenon. 


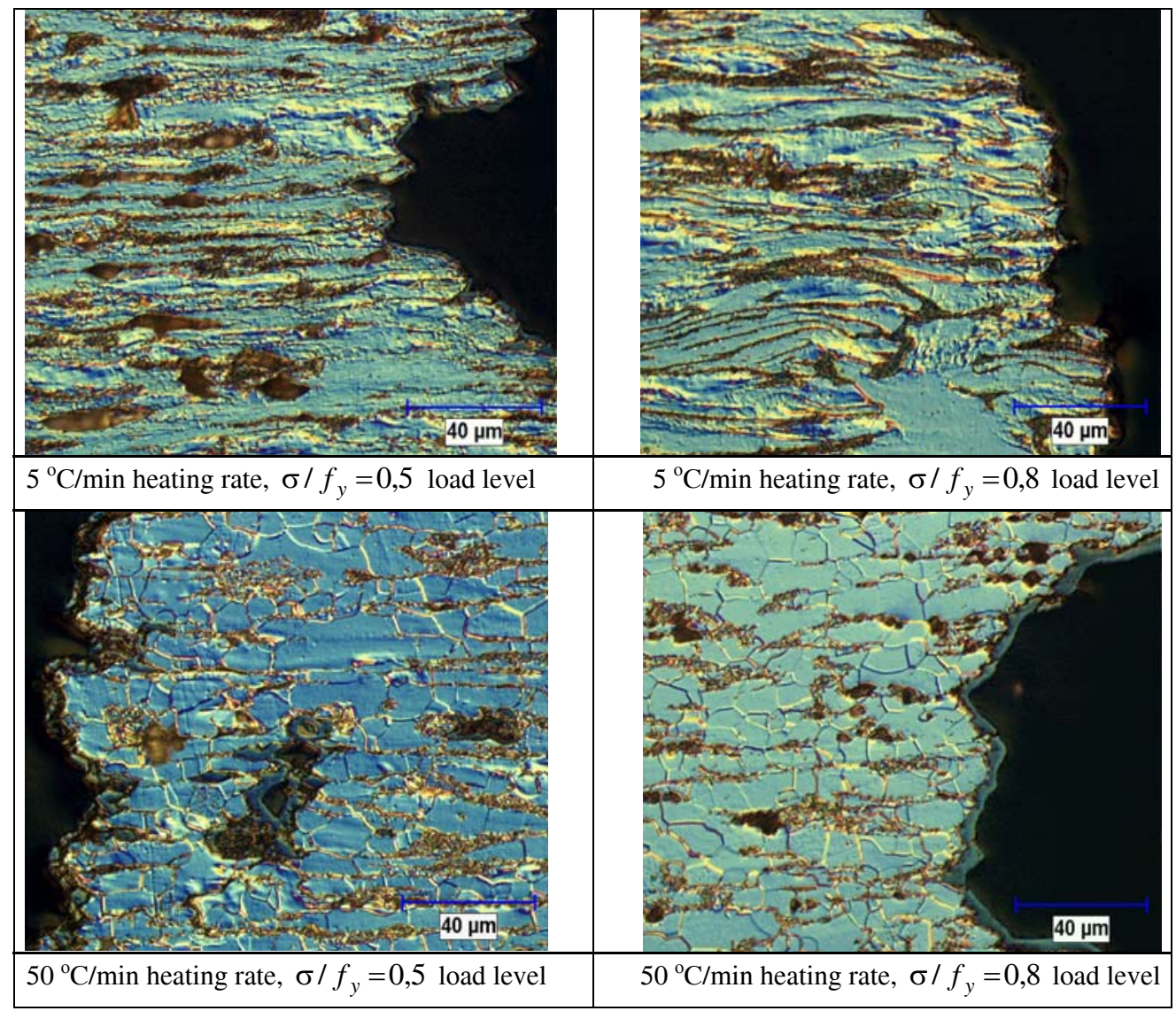

Fig 13. S235JRG2 steel microstructure after mechanical tests

2. A higher heating rate results in the materials higher strength parameters; this is presented with smaller total deformations $\varepsilon(\sigma, T, \tau)$.

3. Probably, an increased heating rate delays the heat-activated weakening processes that lead to the material damage at high temperatures. The material damage critical temperature increases with the heating rate. This critical temperature is accompanied by smaller deformations $\varepsilon_{\mathrm{kr}}$.

4. The metallography confirmed that some structural processes in steel samples were delayed in case of the high heating rate compared to the long-time low heating rate for steel samples. A smaller grain distortion before the sample damage (as specific for brittle materials) was found for a high heating rate.

The tests and result also have a certain importance for steel applications.

\section{References}

1. Anderberg, Y. Modelling Steel Behaviour. Fire Safety Journal, 13(1), 1988, p. 17-26.

2. Lu, W.; Mäkeläinen, P. Advanced Steel Structures. Publication 29, Laboratory of Steel Structures, Helsinki University of Technology, Espoo, Finland, 2003. 116 p.

3. Skowroński, W. Bearing Capacity and Creep Issues for Steel Structures in Fire (Problemy nośności i pełzania konstrukcji stalowych w pożarach). Researches and Monographs b. 62, Opole, 1992. 220 p. (in Polish).

4. Skowroński, W. Fire Safety of Metal Structures. Theory and Design Criteria. PWN, Warszawa, 2004. 207 p.
5. Stowell, E. Z. A Phenomenological Relation Between Stress, Strain Rate, and Temperature for Metals at Elevated Temperatures. Report 1343, NACA, 1957, p. 125-130.

6. ENV 1993-1-2. Eurocode 3 - Design of steel structures Part 1-2: General rules - Structural fire design. European Committee for Standartization, Brussels, 2001. 64 p.

7. Bednarek, Z.; Kamocka, R. Structural Steel Thermal Deformations within a Variable Temperature Field. Engineering and Building (Inżynieria i Budownictwo), 8, 2003, p. 445-457 (in Polish).

8. Bednarek, Z.; Kamocka, R. Analysis of Thermal Deformations of Structural Steels in Variable Thermal Field. Journal of Civil Engineering and Management, Vol X, Suppl 1, 2004, p. 19-22.

9. Explanatory Document for ECCS No.89. EuroNomogram. European Convention for Constructional Steelwork, Brussels, 1996. 6 p.

10. Bednarek, Z. Character and Mechanism of Metals Failure in High Fire Temperatures. Statyba (Civil Engineering), 1(5), 1996, p. 6-13.

11. Bednarek, Z. Impact of Unstable Thermal Conditions on Structural Steel Strength Parameters as Used for the Assessment of Structures' Fire Safety (Studium wpływu nieustalonych warunków termicznych na stosowane przy ocenie bezpieczeństwa pożarowego konstrukcji parametry wytrzymałościowe stali budowlanych). Publishing house PW, 1996. 203 p. (in Polish).

12. Przybyłowicz, K. Basics of Metal Science (Podstawy teoretyczne metaloznawstwa). WNT, Warszawa, 1999. 397 p. (in Polish). 


\section{KAITINIMO GREIČIO ĮTAKOS GAISRO PAVEIKTŲ PLIENŲ CHARAKTERISTIKOMS TYRIMAI}

\section{Z. Bednarek, R. Kamocka}

\section{S antrauka}

Aukšta temperatūra paveiktų plieno konstrukcijų elgsena priklauso ne tik nuo absoliutinès temperatūros, bet ir nuo temperatūros kitimo laike funkcijos bei kaitinimo greičio. Pateiktų tyrimų tikslas - nustatyti kaitinimo greičio ịtaką konstrukcinių plienu stiprumo charakteristikoms. Atlikti eksperimentiniai tyrimai, esant tiesiniam temperatūros augimui su skirtingais kaitinimo greičiais. Visuose bandiniuose įtempių lygis buvo vienodas. Po stiprumo nustatymo bandymų visiems bandiniams atlikta metalografija. Bandymų rezultatai parodè, kad kaitinimo greitis turi didelès įtakos aukšta temperatūra veikiamų plieninių konstrukcijų laikomosios galios parametrams. Ši įtaka turètų būti vertinama atliekant gaisro temperatūra veikiamų plieno konstrukcijų stiprumo skaičiavimus.

Reikšminiai žodžiai: statybinis plienas, kaitinimo greitis, gaisro sąlygos, kritinė deformacija, kritinė temperatūra, stiprumo bandymai.

Zoja BEDNAREK. Prof Dr Sc. The Commander-Rector of the Main School of Fire Service in Warsaw, Poland. Her scientific research deals with the problems of materials and building structural strength at high fire temperatures. Promoter of Doctor thesis concerning the problems mentioned above.

Renata KAMOCKA. Lecturer in mechanics and strength of materials at the Applied Mechanics Institute of the Main School of Fire Service in Warsaw (SGSP, Poland). PhD degree in technical sciences at Lublin University of Technology on Dec of 2005 with the thesis on influence of the heating rate on strength parameters of steel structures. Member of PNTTE Polish Maintenance Society.

Her research interests include the behaviour of materials at high temperatures and under fire conditions as well as modern measuring techniques. 